\title{
Certified Organic Farming: Awareness of Export Oriented Small-Scale Farmers in Sri Lanka
}

\author{
S. M. C. B. Karalliyadda ${ }^{1} \&$ Tsuji Kazunari ${ }^{2}$ \\ ${ }^{1}$ The United Graduate School of Agricultural Sciences, Kagoshima University, Kagoshima, Japan \\ ${ }^{2}$ Department of Agricultural Economics, Faculty of Agriculture, Saga University, Saga, Japan \\ Correspondence: Tsuji Kazunari, Department of Agricultural Economics, Faculty of Agriculture, Saga University, \\ 1-Honjo-machi, Saga-shi, Saga-ken, 840-8502, Japan. Tel: 81-80-9064-7155. E-mail: 18974002@edu.cc.saga-u.ac.jp
}

Received: October 17, 2018

Accepted: November 15, $2018 \quad$ Online Published: November 29, 2018

doi:10.5539/jsd.v11n6p259

URL: https://doi.org/10.5539/jsd.v11n6p259

\begin{abstract}
This study aimed at investigating Sri Lankan small-scale certified organic (CO) farmers' awareness on their adopted organic standards, the third-party certification body, internal control system, Fairtrade certification, and conditions of contracts with coordinating organizations. A cross-sectional survey was conducted among a randomly selected sample of $202 \mathrm{CO}$ farmers who were linked with five coordinating organizations. Primary data was collected using a structured questionnaire along with key informant discussions and field observations. Data were analyzed using descriptive statistics to generate simple summaries and tendencies. According to the results, CO farmers are organized as farmer organizations that were initiated as out-grower groups of coordinating organizations. All $\mathrm{CO}$ farmers are unaware of the adopted organic standards. The majority are unaware of the third-party certification body (83\%), and the internal control system (81.7\%). Perhaps this is due to their exclusion in managing certification related aspects and submissive decision-making behavior. However, many of them are aware of Fairtrade certification (56.4\%) as it provides a wide spectrum of additional benefits covering production, marketing, and farmers' welfare. Farmers are also aware of their contracts (verbal or written) with coordinating firms $(62.2 \%)$ but hardly conscious of their conditions. In some contracts, conditions are unfairly distributed among stakeholders. Therefore, the study recommends enhancing small-scale farmers knowledge not only the production aspects but also certification, quality assurance, administration, and marketing as well. Meanwhile, mediating the partnership among stakeholders by a government body is also recommended to avoid power abuses among stakeholders.
\end{abstract}

Keywords: organic farming, awareness, certification, standards, fairtrade, contracts

\section{Introduction}

Organic farming is becoming a leading sector in developing countries such as India, Mexico and Ethiopia due to its chain of economic, ecological and social benefits for all stakeholders. The certification of organic products assures the authenticity and positively influences consumers' purchasing (Daugbjerg, Smed, Andersen, \& Schvartzman, 2014; Janssen \& Hamm, 2012). Thus, Certified Organic farming (CO farming) brings more benefits for producers compared with non-certified organic farming. There are specific technicalities associated with CO farming, such as Organic Standards (OS) and quality assurance. CO farmers' awareness on OS and quality assurance aspects is important for their effective field implementation. Since the implementation of OS and quality assurance are parts of the production process, $\mathrm{CO}$ farmers' awareness on those aspects improves their economic liberalization and decision-making (Qiu, Wang, Zhang, \& Xu, 2016; Zhong, Yang, \& Chen, 2015). Previous studies have cited that, unawareness and unfamiliarity of essential aspects of $\mathrm{CO}$ farming challenge farmers' decision making (Khanna \& Tripathee, 2018; Marsh, Zoumenou, Cotton, \& Hashem, 2017; Singh \& George, 2012). Moreover, if CO farmers are unaware of OS and quality assurance aspects, they may be unable to differentiate $\mathrm{CO}$ farming from non-certified organic farming and may have difficulties in complying with OS and maintaining the expected quality levels. Due to economic burdens, small-scale CO farmers arrange partnerships with organic product-based firms as partnerships minimize farmers' cost for quality assurance and link them with different markets (Barrett, Browne, Harris, \& Cadoret, 2001). In such cases, these firms become coordinators of small-scale CO farmers and are responsible for managing their member farmers' adoption of OS and assurance of quality of organic products. If partnerships between $\mathrm{CO}$ farmers and coordinating firms rely on contracts or 
agreements, not only the unawareness of OS, and quality assurance aspects but also the conditions of contracts may increase farmers' information reliance on partnering firms and perhaps expose farmers vulnerable to fraudulent contracts or business transactions. Therefore, farmers' awareness of OS and quality assurance aspects are important for them to make viable decisions for their wellbeing. There is evidence about organic farmers' knowledge on production aspects such as organic farming practices (Farouque \& Sarker, 2018; Hameed \& Sawicka, 2016), but limited attention has been given to study farmers' awareness on the type of OS they adopt, certifications, and contracts. As lack of understanding of CO farmers' awareness can suppress the development of knowledge enhancement strategies and improving the human capital in the organic industry, this remains as a significant knowledge gap which needs to be addressed with suitable empirical investigations.

In Sri Lanka, organic farming has proven benefits for human ecology, economy, and society. Currently, Sri Lankan organic agriculture sector holds around 96,318 ha of land and nearly 8,695 producers, 189 processors, and 311 exporters (Willer \& Lernoud, 2017). Since many organic products are oriented for international markets, certificate of conformity for OS is a prerequisite for export-oriented organic products (Export Development of Organic Products Regulations 2014, 2014). Current organic products are compliant with different OS (E.g., JAS, EU) (Vidanapathirana \& Wijesooriya, 2014) and sometimes associated with Fairtrade certifications (Barrett, Browne, Harris, \& Cadoret, 2001; Gunarathne, 2015; Qiao, Halberg, Vaheesan, \& Scott, 2016). According to Vidanapathirana and Wijesooriya (2014), there are two main leading international organizations (i.e. Control Union and Institute for Marketecology) and one local organization (i.e. SriCert) to certify the organic products. As per the authors' knowledge, small-scale CO farmers' awareness of their OS, quality assurance and contract related aspects have not so far been investigated in Sri Lankan context. Therefore, this study aimed at investigating small-scale CO farmers' awareness on their adopted organic standards; third-party certification body; an internal control system; Fairtrade certification and conditions of the contracts with coordinating firms. The following sections begin with a brief explanation of OS and quality assurance process of small-scale CO farmers and end with some recommendations to improve CO farmers' awareness and their role in $\mathrm{CO}$ farming sector.

\section{Background of Organic Standards, Inspection and Certification of Organic Standards, and Fairtrade Certification.}

\subsection{Organic Standards}

Organic agriculture is "a system for crops, livestock and fish farming that emphasizes environmental protection and the use of natural farming techniques" (Morgera, Caro, \& Duran, 2012). Currently, organic farming practices are technically well defined as OS and recognized in three categories as international voluntary standards, national standards and private labels (Scialabba, 2014).

\subsubsection{International Voluntary Organic Standards}

Codex Alimentarius Commission's guidelines for production, processing, labelling, and marketing of organically produced foods are the international minimum guidelines for organically produced foods (Codex Alimentarius Commission, 1999). They are established to harmonize organic products at the international level and to help governments establishing national OS. These guidelines are not compulsory for any party to adopt for their OS. But, due to Technical Barriers to Trade (TBT) agreements of the World Trade Organization (WTO), these are important in international trade. Thus, member countries of WTO are obliged to accept the international standards in case of disputes (Agra, 2011). Sri Lanka as a member country has considered these guidelines to develop national standards for both organic agriculture production and processing (Sri Lanka Standards Institution, 2007). The "Common Objectives and Requirements of Organic Standard" of the International Federation of Organic Agricultural Movement (IFOAM) is recognized as the private sector's correspondent to the Codex Alimentarius guidelines (Food and Agriculture Organization, 2014). According to the membership directory of IFOAM, in 2017, there were 848 affiliates from 121 countries including six affiliates from Sri Lanka (E. g., Bio Food Pvt Ltd, Good Market) (International Federation of Organic Agricultural Movements, 2017).

\subsubsection{National Organic Standards (Mandatory and Voluntary)}

Some countries have established their own national OS. Products to be recognized as organic in these countries should be compliant with their national OS. In 2016, 87 countries had national organic farming related legislation and standards while 17 countries were drafting those (Huber \& Schmid, 2017). Some of these standards are mandatory (E.g., EU, Japan) for producers and processors while others are voluntary (E.g., Australia).

Besides that, bilateral agreements between countries have been made to accept the national OS and controlling 
system of the partner countries. This reduces the trade barriers of organic products between partner countries and allows selling locally certified products in the partner countries without additional regulations. As an example, the European Union has recognized standards of twelve countries as equivalent to those of the European Union's system known as the "third country list" (Huber \& Schmid, 2017). In Sri Lanka, the recently established National Organic Control Unit is serving the purpose of obtaining the third country registration.

\subsubsection{Private Organic Labels}

Private organizations in some countries have established their own OS besides the national OS in the act, particularly considering the consumer demands (E.g., "Bio-swiss" in Switzerland and "Demeter" in Germany).

\subsection{Inspection and Certification of Organic Standards}

Inspection and Certification provides written and reliable assurances for organic products, recognizing operators' compliance with OS. This provides certificates of conformity for compliant operators enabling them to use the label of OS on their organic products. There are two certification methods: Third-party certification; and Participatory guarantee system. In third-party certification, independent certification bodies conduct the certification adhering to the procedures recommended by the institutes responsible for OS (Scialabba, 2014). This includes pre-assessments and documentation reviews of the operator's facilities and production operations. Moreover, a field audit is also conducted in a random sample for further clarifications. The operator or representative of the operator is responsible for meeting the certification costs (Hatanaka, Bain, \& Busch, 2005). After the initial certification, annual or more frequent inspections are conducted by the certifier either as announced visits or unannounced visits.

Participatory Guarantee System (PGS) is a locally oriented certification system which certifies operators through an active participation of stakeholders (International Federation of Organic Agriculture Movements, 2014). The certification process is similar to third-party certification. However, it includes the active participation of farmers and consumers it serves (Källander, 2008). Thus, all stakeholders become aware of the certification process. Currently, there are nearly 130,000 producers in 250 PGS around 73 countries worldwide (Katto-Andrighetto \& Kirchner, 2017).

\subsection{Group Certification and Internal Control System}

Group certification enables certification of small-scale producers as a group. In this process, the internal control system and the group coordinator act as key features. The internal control system is a part of a documented quality assurance system. An external certification body delegates regular inspections of individual group members to an identified body or unit within the certified operator (International Federation of Organic Agriculture Movements, 2014). The certification bodies assess the proper functioning of the ICS and inspect the field implementation of OS among randomly selected 10 to $20 \%$ of the members of the group. The group coordinator keeps records, organizes the internal control system and conducts an annual inspection of all the members in the group (Barrett, Browne, Harris, \& Cadoret, 2001). The internal control system can be managed either by the producers themselves, a contracted NGO, government agencies or by staff from the coordinator (Källander, 2008).

\subsection{Fairtrade Certification}

Fairtrade certification is a producer focused equitable marketing system which provides economic benefits directly from customers to the producers. When small producer organizations are having Fairtrade certifications, they are entitled to use the Fairtrade premiums in different ways such as an investment in producer organizations and services for farmers and communities (Fairtrade International, 2016).

According to Fairtrade International (2016), Sri Lanka is one of the top five Asian countries where there are many Fairtrade registered farmers and workers. In 2014, there were 24,400 farmers and workers registered as Fairtrade benefit receivers under seven Small Producers' Organizations and twelve Hired Labor Organizations. Out of these, three Small Producers' Organizations had 3600 farmers under Fairtrade tea certification (Fairtrade International, 2016). Sri Lanka is also a leading adopter of Fairtrade certification system in the Asia and Pacific region as it achieved the first place in gender balance, second place in producers, third place in the number of farmers and workers and sixth place in receiving premium benefits (Fairtrade Network of Asia and Pacific Producers, 2016). Since most of the organic food importing countries demand organic products with Fairtrade certificates $29 \%$ of organic product exporting companies in Sri Lanka has obtained Fairtrade certificates while many others are interested in obtaining Fairtrade certificates in future (Vidanapathirana \& Wijesooriya, 2014). 


\section{Method}

A cross-sectional survey was selected as the research design in this study. As there were no reliable sources to identify the population and the sampling framework, a list of organic food-related organizations which were cited in the study conducted by Vidanapathirana and Wijesooriya (2014), was selected to locate small-scale CO farmers. Contact details of these organizations were obtained from their official websites and personal contacts. These organizations are recognized as coordinating organizations of small-scale farmers and also, they hold the certificate of conformity for OS on behalf of their CO farmers. Formal requests were made to coordinating organizations to conduct the survey among a sample of their member $\mathrm{CO}$ farmers. Five coordinating organizations agreed to link their farmers with the survey. Four of these coordinating organizations were organic product related processing and exporting firms and the other one was an independent organic farmers' association. All farmers were grouped as farmer organizations (FO). These FOs were initiated as out-grower groups of organic food-related companies. The independent farmer association also consisted of several FOs and was initially linked with one of the above-mentioned processing and exporting firm. Currently, this farmer association has an independent administrative structure. However, it still provides their member farmers' harvest to the former coordinating firm.

A sample of 202 small-scale farmers was randomly selected from the lists provided by each coordinating organizations. These $\mathrm{CO}$ farmers mainly cultivate tea, coconut and spices. A structured questionnaire was used in primary data collection along with in-depth discussions with officials of coordinating organizations. Moreover, farm records were observed after obtaining the permission from the farmers to triangulate some of the self-reported information of farmers. Data were analyzed using descriptive statistics to develop simple summaries and tendencies.

\section{Results and Discussion}

\subsection{Socioeconomic Background of CO Farmers}

According to the results, the average age of farmers is 56 years and most of them are males. Many farmers (79.2\%) have higher than the primary level of education and are working as full-time farmers $(65.3 \%)$ with an average of 7 years of experience in organic farming. Therefore, farmers seem to have enough capacity to understand at least the basic features of OS, quality assurance, certification, contracts etc.

Table 1. Socioeconomic background of $\mathrm{CO}$ farmers $(\mathrm{N}=202)$

\begin{tabular}{llr}
\hline Socioeconomic characteristics & & Value \\
\hline Average age (Years) & & $56(\mathrm{SD}=12.2)$ \\
\hline \multirow{2}{*}{ Gender (\%) } & Male & 64.9 \\
& Female & 35.1 \\
\hline & Primary & 20.8 \\
Education level (\%) & G.C.E. OL & 47.0 \\
& G.C.E.AL & 27.7 \\
& Other & 4.5 \\
\hline \multirow{2}{*}{ Farming type (\%) } & Full time & 65.3 \\
& Part-time & 34.7 \\
\hline Average experience in organic agriculture (Years) & & $7(\mathrm{SD}=4.7)$ \\
\hline
\end{tabular}

Note: G.C.E. $\mathrm{OL}=$ General Certificate of Ordinary Level, $\mathrm{AL}=$ Advanced Level

Source: Survey 2017

\subsection{Awareness on Organic Standards and Quality Assurance Aspects}

According to the discussions with officials of coordinating organizations, farmers follow OS such as JAS, USDA, EU, Bioswiss, Demeter etc. There are no farmers who follow Sri Lankan OS. Some farmers follow more than one OS. Besides farmers' awareness of organic farming practices, all farmers are unaware of which of the OS or OSs that they follow (Table 2). Although emblems of these OS are printed in farm record books provided by 
some coordinating organizations, none of the farmers recognizes those as emblems of OS. Discussions with farmers revealed that they can not distinguish organic farming from CO farming. They differentiate themselves from other organic farmers by their membership to the FOs. According to farmers' views, they have never been communicated about the types of OS that they adopt. They submissively follow the instructions given by the officials of coordinating organizations.

According to the officials of coordinating organizations, all the farmers in this study are certified by Control Union. However, many farmers are unaware of that their certification body as the Control Union (83\%) while few of them are aware of it (9.4\%) (Table 2). During field observations, it could identify that mostly all contacted farmers have been visited at least one time by the inspectors of Control Union. During their inspections, they have signed the farm record books with their official seals. Few farmers mentioned that their farms are inspected by an officer who comes from the capital Colombo. However, none of the farmers realizes the purpose of such visits. Authors found that these inspectors communicate less with the farmers compared with their clients (Coordinating organization). Therefore, these farmers seem to be less aware of third-party certification bodies.

Table 2. Farmers' awareness on $\mathrm{CO}$ farming related aspects $(\mathrm{N}=202)$

\begin{tabular}{llr}
\hline Characteristic & Farmers' response & $\%$ \\
\hline \multirow{2}{*}{ Type of adopted organic standard } & Organic standards (USDA, JAS, EU etc.) & 0 \\
& None & 0 \\
& Not aware & 100 \\
\hline & Control Union & 9.4 \\
& Institute of Marketecology & 0 \\
Third-party certification agency & Sri Lanka Standards Institute & 7.5 \\
& Local certifier (SriCert) & 0.0 \\
& None & 0.0 \\
Internal Control System & Not aware & 83.0 \\
\hline \multirow{2}{*}{ Availability of the Fairtrade certification for organic } & Aware & 18.3 \\
products & Not aware & 81.7 \\
\hline Sour & Available & 56.4 \\
& Not available & 11.9 \\
\hline
\end{tabular}

Source: Survey 2017

All the coordinating organizations have established their own internal control systems as required for group certification. The composition of each coordinating organizations' internal control system is different. Some coordinating firms have recruited their own staff while others have outsourced the service. The recruited staff does not consist of farmers but young personnel who have an education background of agriculture or who are experienced field officers. They continuously inspect farmers farming practices and advise them to comply with OS. According to the results, many farmers $(87.1 \%)$ do not know about the existence of these internal control system and their functions (Table 2). They are only aware that there are officers who regularly visit them and advise them about farming practices. However, during field observations, it was realized that there are several officials who visit organic farms for different purposes (E.g., purchasing officers, extension officers, third-party certifiers etc.). But farmers are unable to clearly distinguish their purpose of visit. Therefore, there are tendencies for farmers to seek advises from any official who visits their farms. If farmers contact visitors such as agrochemical salespersons, they are vulnerable of getting misinformation of organic farming. Some coordinating organizations have forecasted this risk and have requested farmers to avoid any unknown visitors without prior approval from them. However, such strategies tend to barricade the unannounced visits by certification agencies by then limiting the management of farmers' compliances with OS. Therefore, farmers should be informed of all the background details about their management including the officials they deal with. 
Most of the coordinating organizations mentioned that their farmers are eligible for Fairtrade benefits. Many farmers $(54.6 \%)$ are aware of its availability while others mentioned that they are unaware of it $(37.1 \%)$ or not available (11.9\%) (Table 2). Perhaps this is due to that these benefits are additional gains of these farmers from usual gains of sales. Moreover, it could be due to the wider prospect of services which cover both individuals' and community's well-being (Fairtrade International, 2016). Some farmers refer these Fairtrade benefits as "annual premiums" as they are receiving benefits once a year. However, among all the benefits farmers are unable to differentiate Fairtrade associated benefits from other benefits they receive from coordinators. Hence, they refer to all the benefits as services they get from their coordinators. These services have been one of the main reasons to adopt certified organic farming. Knowing this, some coordinators use it to gain farmers' compliance for OS. Although, few coordinators are effectively using the Fairtrade benefits to improve the living conditions of their farmers and communities while many others are found to be still developing plans to use it. All the services by coordinators can be mainly categorized according to three main areas i.e. production, marketing and welfare development (Table 3).

\subsection{Awareness of Fairtrade Certification}

Table 3. Services from coordinators $(\mathrm{N}=202)$

\begin{tabular}{llr}
\hline Services & Focus & $\%$ \\
\hline Training & & 92.5 \\
Providing farming tools & & 80.1 \\
Providing planting materials (nursery plants) & Production & 63.2 \\
Providing approved organic fertilizers & & 56.7 \\
Providing approved pesticides & \multirow{2}{*}{ Marketing } & 25.9 \\
\hline Product purchasing & & 92.0 \\
Product transportation & & 84.1 \\
\hline Developing rural infrastructure & welfare Development & 30.3 \\
Facilitating children education & & 21.9 \\
Providing financial assistances in emergencies & & 16.9 \\
Women empowerment & & 10.0 \\
\hline SOurce: Survy 2017
\end{tabular}

Source: Survey 2017

According to the results, the main attention is given to the production-related services and marketing related services while the least attention is given for welfare development. The production-related services mainly included the provision of training and materials. Trainings (92\%) are oriented basically providing knowledge and skills to produce organic fertilizers and pesticides (biodynamic preparations, liquid fertilizers, Bordeaux mixture, etc.) as they are the main substitutes for synthetic agrochemicals. Materials mainly included farm tools (80.1\%), nursery plants (63.2\%), approved organic fertilizers (56.7\%) and approved pesticides (25.9\%) (Table 3). The marketing related services are mainly about purchasing the organic produce from farmers $(92.0 \%)$ and transportation services to their processing locations (84.1\%) (Table 3). Fewer services are provided to develop welfare development, which include the development of rural infrastructure $(30.3 \%)$ (E.g., concrete bridges, repairing public wells), facilities to improve the education of the children (21.9\%) (E.g., developing pre-schools, scholarships for outstanding students), financial assistance in emergencies (18.2\%) and empowering women $(10 \%)$ (Table 3).

\subsection{Awareness on The Contract with Coordinators}

Results show that most farmers $(62.2 \%)$ are aware of their contract with their coordinators and mentioned it as a written $(88.5 \%)$ or verbal (11.5\%) agreement (Table 4). But discussions revealed that they are not much aware of the conditions of the contract. Some of these written contracts can be observed in the farmers' field books (Figure1). As farmers have given less attention to maintain farm records some farmers are even unaware of the presence of written agreement in their field books. However, the provision of these agreements covers only the production aspects by farmers. None of the conditions are there for coordinating firms. Therefore, agreements between farmers and coordinating firms with unfair conditions have a possibility for coordinating firms to abuse 
their power over contracts and to mishandle the rights of the farmers.

Table 4. Farmers' awareness of the availability and the type of contract $(\mathrm{N}=202)$

\begin{tabular}{llr}
\hline Question & Farmers' response & $\%$ \\
\hline \multirow{2}{*}{ Availability of a contract with the coordinator } & Yes & 62.2 \\
& No & 37.8 \\
\hline \multirow{2}{*}{ Type of the contract } & Verbal & 11.5 \\
& Written & 88.5 \\
\hline
\end{tabular}

Source: Survey 2017

\section{Agreement of the Producer}

Shareholders:

Producer.

1. I am abided to follow the most important organic agriculture standards which are listed below.

a. Not to use or keep synthetic chemical substances such as fertilizers, weedicides, insecticides, fungicides, in the farm.

b. Enhance the soil quality and the fertility by crop rotations and planting legumes.

c. Use of natural methods to control insect and disease, and to use manual weeding methods to control weeds.

d. Use of organically developed planting materials

2. Labeling and selling the products of organic and in transition separately without letting any of the field to contaminate from prohibited substances

3. Certifying that I farm in the same land area which applied for the organic program, products are only from the organic land and those are produced according to the internal organic agriculture standards.

4. Allowing the international third-party inspectors, licensed officer of the coordinators to enter to the buildings and farm sites to provide full assistance for their inspections

5. Maintaining field maps, input and sales records updated

6. To protect the labor rights and assist their sustainable development if there are hired labors

If my products are not according to the above standards, I will inform it to the collector or the certificate holder. In such situations, I will not sell my products either as organic or intransition products.

Producers' signature

Date

\section{Coordintor's signature}

Date

Figure 1. A sample of a written agreement between a farmer and a coordinating organization

Source: Survey 2017

\section{Conclusion}

This study mainly attempted to investigate the certified organic farmers' awareness of some of the aspects in certified organic farming including Fairtrade certification and contract with coordinating organizations. A questionnaire survey was used to gather data from 202 certified organic farmers along with field observations and key informant discussions. According to the results, agricultural firms, that process or export organic products arrange FOs as out-grower groups in locations which facilitates their procurements. Although FOs are to be independently functioned, many FOs are still under the direct and indirect influences of coordinating firms. The incompatibility of objectives/ unevenness in the relationship between coordinating firms and farmers have made many farmers passive and submissive behaviour in decision making. Despite nearly 7 years of experience 
in organic farming, the majority are unaware of the type of organic standards adopted, their third-party certifier, and availability of the Internal Control System. This is perhaps due to the incompatibility of training and education programs or intentional or unintentional ignorance of coordinating firms to make farmers aware of those aspects. However, the majority of farmers are aware of Fairtrade certificates as they receive a wide spectrum of benefits as supplements to their usual trades and as it is also one of the motives for farmers to join these FOs. The services for farmers including Fairtrade benefits are unequally distributed in different scopes while prioritizing on production and marketing aspects rather developing the wellbeing of farmers and their communities. Since certified organic farming increases the social capital by encouraging social organizations it requires information not only about agroecological practices but also certification and marketing aspects (Jouzi et al. 2017). Therefore, this study first recommends educating farmers about all the aspects in certified organic farming for FOs to have more liberalized administrative activities and decision making. So far government involvement in certified organic farming is less recognized, therefore this study further recommends incorporating monitoring mechanism by government institutes (E.g., Department of Agriculture) to evaluate the relationships between farmers and coordinating firms. Lastly, if farmers are linked with contracts either verbally or written, these government monitoring institutes should attend to investigate them to minimize the power abuses from stronger bargaining parties.

\section{Acknowledgements}

The authors highly appreciate the coordinating organizations for their cooperation in data collection. Moreover, the authors acknowledge the $\mathrm{CO}$ farmers in this study for voluntarily spending their valuable time to conduct this study. Last but not least, authors acknowledge the comments given by fellow postgraduate students to improve the quality of this manuscript.

\section{References}

Agra, I. M. (2011). Organic Farming Standards. Retrieved from https://ec.europa.eu/agriculture/sites/agriculture/files/events/2011/organic-africa-2011/agra_en.pdf

Barrett, C. B., Bachke, M. E., Bellemare, M. F., Michelson, H. C., Narayanan, S., \& Walker, T. F. (2012). Smallholder Participation in Contract Farming: Comparative Evidence from Five Countries. World Development, 40, 715-730. https://doi.org/10.1016/j.worlddev.2011.09.006

Barrett, H. R., Browne, A. W., Harris, P. J. C., \& Cadoret, K. (2001). Smallholder Farmers and Organic Certification: Accessing the EU Market from the Developing World. Biological Agriculture \& Horticulture, 19, 183-199. https://doi.org/10.1080/01448765.2001.9754920

Codex Alimentarius Commission (1999). Guidelines for The Production, Processing, Labelling and Marketing of Organically Produced Foods. (CAC/GL 32-1999). Rome, Italy: Codex Alimentarius Commission.

Daugbjerg, C., Smed, S., Andersen, L. M., \& Schvartzman, Y. (2014). Improving Eco-labelling as an Environmental Policy Instrument: Knowledge, Trust and Organic Consumption. Journal of Environmental Policy \& Planning, 16, 559-575. https://doi.org/10.1080/1523908X.2013.879038

Export Development of Organic Products Regulations 2014 Export Development Act, No. 40 OF 1979 (Ministry of Industry and Commerce Sri Lanka 07/10/2014).

Fairtrade International. (2016). Monitoring the Scope and Benefits of Fairtrade: Seventh Edition, 2015.Retrieved from

http://www.fairtradeamerica.org/ /media/fairtrade\%20america/files/reports/2015-fairtrade-monitoring-scop e-benefits_web.pdf

Fairtrade Network of Asia and Pacific Producers. (2016). Annual Report 2015. Retrieved from http://www.fairtradenapp.org/wp-content/uploads/2014/05/NAPP-Annual-Report-2015-Full-Length.pdf

Farouque, M. G., \& Sarker, M. A. (2018). Farmers knowledge and practice of organic vegetable cultivation: A field level study of two villages from Bangladesh. Journal of Agricultural Extension and Rural Development, 10, 99-107. https://doi.org/10.5897/JAERD2018.0948

Food and Agriculture Organization. (2014). Organic Agriculture: Frequently Asked Questions. Retrieved from http://www.fao.org/organicag/oa-faq/oa-faq2/en/

Gunarathne, L. H. P. (2015). Comparative Efficiency of Organic and Conventional Tea and Its Rural Development Implications in Sri Lanka. In A. Markandya, \& S. Setboonsarng (Eds.), Organic Agriculture and Post-2015 Development Goals: Building on the Comparative Advantage of Poor Farmers (pp. 279290). Asian Development Bank. Retrieved from https://think-asia.org/handle/11540/4411 
Hameed, T., \& Sawicka, B. (2016). Farmers' Knowledge About the Economic and Production Aspect of Organic Farming. Episteme, 30.

Hatanaka, M., Bain, C., \& Busch, L. (2005). Third-party certification in the global agrifood system. Food Policy, 30, 354-369. https://doi.org/10.1016/j.foodpol.2005.05.006

Huber, B., \& Schmid, O. (2017). Standards, Regulations and PoliciesStandards and Regulations. In H. Willer, \& J. Lernoud (Eds.), The World of Organic Agriculture.Statistics and Emerging Trends 2017 (Version 1.3 of February, pp. 150-157). Bonn,: Research Institute of Organic Agriculture (FiBL) Frick, and IFOAM-Organics International.

International Federation of Organic Agriculture Movements. (2014). The IFOAM NORMS for Organic Production and Processing: Version 2014. Germany. Retrieved from https://www.ifoam.bio/

International Federation of Organic Agriculture Movements. (2017). Membership E-Directory, 2017. Retrieved from https://www.ifoam.bio/sites/default/files/directory2017_highres.pdf

Janssen, M., \& Hamm, U. (2012). Product labelling in the market for organic food: Consumer preferences and willingness-to-pay for different organic certification logos. Food Quality and Preference, 25, 9-22. https://doi.org/10.1016/j.foodqual.2011.12.004

Jouzi, Z., Azadi, H., Taheri, F., Zarafshani, K., Gebrehiwot, K., van Passel, S., \& Lebailly, P. (2017). Organic Farming and Small-Scale Farmers: Main Opportunities and Challenges. Ecological Economics, 132, 144 154. https://doi.org/10.1016/j.ecolecon.2016.10.016

Källander, I. (2008). Participatory guarantee systems-PGS. Retrieved from https://www.ifoam.bio/sites/default/files/page/files/pgsstudybyssnc_2008.pdf

Katto-Andrighetto, J., \& Kirchner, C. (2017). Participatory Gurantee Systems in 2016. In H. Willer, \& J. Lernoud (Eds.), The World of Organic Agriculture.Statistics and Emerging Trends 2017. (Version 1.3 of February, pp. 157-158). Bonn,: Research Institute of Organic Agriculture (FiBL) Frick, and IFOAM-Organics International.

Khanna, S. A., \& Tripathee, L. (2018). Organic Certification: A Case Study of Organic Valley, Nepal. International Journal of Applied Agricultural Sciences, 4, 14. https://doi.org/10.11648/j.ijaas.20180401.13

Marsh, L., Zoumenou, V., Cotton, C., \& Hashem, F. (2017). Organic farming: knowledge, practices, and views of limited resource farmers and non-farmers on the Delmarva Peninsula. Organic Agriculture, 7, 125-132. https://doi.org/10.1007/s13165-016-0150-x

Morgera, E., Caro, C. B., \& Duran, G. M. (2012). Organic Agriculture and the Law (FAO Legislative Study No. 107).

Qiao, Y., Halberg, N., Vaheesan, S., \& Scott, S. (2016). Assessing the social and economic benefits of organic and Fairtrade tea production for small-scale farmers in Asia: a comparative case study of China and Sri Lanka, 31, 246-257. https://doi.org/10.1017/S1742170515000162

Qiu, H.-G., Wang, X.-B., Zhang, C.-P., \& Xu, Z.-G. (2016). Farmers' seed choice behaviors under asymmetrical information: Evidence from maize farming in China. Journal of Integrative Agriculture, 15, 1915-1923. https://doi.org/10.1016/S2095-3119(15)61326-0

Scialabba, N. E.-H. (2014). Certification in Organic Agriculture: Intersessional Meeting of the Intergovernmental Group on Tea Rome, 5-6 May 2014. Retrieved from http://www.fao.org/fileadmin/templates/est/meetings/tea_may14/Organic_Agriculture_Certification.pdf

Singh, S., \& George, R. (2012). Organic Farming: Awareness and Beliefs of Farmers in Uttarakhand, India. Journal of Human Ecology, 37, 139-149. https://doi.org/10.1080/09709274.2012.11906458

Sri Lanka Standards Institution. (2007). Organic Agriculture Production and Processing (Sri Lanka Standard, 1324: 2007). Colombo, Sri Lanka: Sri Lanka Standards Institution.

Willer, H., \& Lernoud, J. (2017). The World of Organic Agriculture.Statistics and Emerging Trends 2017. (Version 1.3 of February). Bonn: Research Institute of Organic Agriculture (FiBL) Frick, and IFOAM-Organics International.

Zhong, B., Yang, F., \& Chen, Y.-L. (2015). Information empowers vegetable supply chain: A study of information needs and sharing strategies among farmers and vendors. Computers and Electronics in Agriculture, 117, 81-90. https://doi.org/10.1016/j.compag.2015.07.009 


\section{Copyrights}

Copyright for this article is retained by the author(s), with first publication rights granted to the journal.

This is an open-access article distributed under the terms and conditions of the Creative Commons Attribution license (http://creativecommons.org/licenses/by/4.0/). 